\title{
The Saudi Discourse Towards Iran: A Study of The United Nations General Assembly Speeches $^{(*)}$
}

\author{
Hijab Alqahtani, \\ Assistant Professor, \\ Shaqra University
}

الملخص

يقوم الباحث في هذه الدراسة بتحليل الخطاب السياسي السعودي الموجه إلى إيران

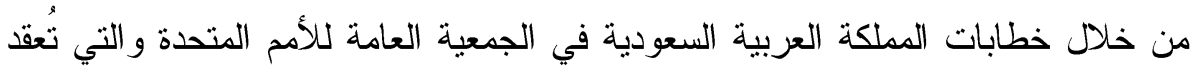
كل عام. اعتمد الباحث في منهجية البحث على استخدام منهج تحليل الخطاب النقدي. تشكل الإطار النظري للار اسة في ضوء ما يجري في منطقة الخليج العربي وحرب اليمن و الأوضاع في سوريا والتذخل الإيراني في هذه الصراعات وفي أماكن أخرى. يقوم البحث على افتراض وجود تغيير في الخطاب الدبلوماسي السعودي تجاه إيران في السنوات الاخيرة. وتهدف الدراسة بشكل رئيس إلى الإجابة على سؤال البحث الاساسي

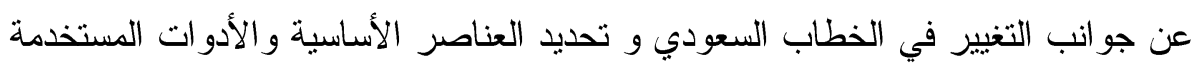
في رصد هذه التغييرات. استخدم الباحث في التحليل الأساسي منهج "فوركلاف" في تحليل الخطاب، وفي التحليل الثانوي اعتمد الباحث على عمل مقارنة ومقاربة بين ملامح منتقاة من الخطاب السعودي بغية الوصول إلى نتائج توضح جوانب التغيير في الخطاب السعودي. خلصت الدراسة إلى أن الخطاب السياسي السعودي يخلو من العدائية خلال تلك بلك الفترة بالر غم من القلاقل التي تثيرها إيران وخرقها الواضح للأعر اف السياسية والاتفاقات الدولية. كما أن هذا التغيير في الخطاب السياسي السعودي كان بسبب السلوك السياسي الاير اني في المنطقة.

${ }^{(*)}$ Bulletin of the Faculty of Arts Volume 79 Issue 2 January 2019 


\begin{abstract}
This paper analyzes the Saudi diplomats' discourse in the General Assembly of the United Nations (UN) using the theoretical framework and methodology of Critical Discourse Analysis (CDA) in light of the Arab Gulf crisis as to the war in Yemen and Syria, and the Iranian intervention in these conflicts as well as in other countries in the region. Based on the hypothetical Saudi research work, there have been remarkable changes in the Saudi diplomats' discourse towards Iran. (Thus this research trying to answer this question: what are the Changing Aspects of "Saudi Political Discourse" towards Iran). The main objective is to identify the basic elements and implemented techniques of discourse which mark the Saudi changing attitude towards Iran. The aim is to determine the Saudi political shifts towards Iran. This paper proceeds to signal via primary analysis of the Saudi discourse (which focuses on Saudi diplomats' speeches at the UN General Assembly) which essentially relies on Fairclough's methodological approach of CDA. The secondary analysis compares and contrasts selected aspects of Saudi discourse with the aim of arriving at the findings. To conclude this study reveals that the Saudi diplomatic discourse remained non-aggressive throughout these years in spite of such Iranian political problems as the remarkable violation of diplomatic norms and international agreements. Additionally the changing discourse of Saudi diplomacy towards Iran is due to the changing political behavior of Iran in the Gulf area.
\end{abstract}

Keywords: linguistics - Critical Discourse Analysis (CDA) persuasive techniques - corpus analysis - Kingdom of Saudi Arabia KSA - Iran.

\title{
1. Introduction
}

Discourse Analysis emerged in the 1960s when changes in linguistic studies reflected radical transformations in disciplinary and cross-disciplinary fields and there was a new focus on verbal and nonverbal socio-cultural and political discourse (Van Dijk, 1997). Since the focus here is specifically the discourse of diplomacy, it is useful to distinguish between Discourse Analysis (DA), Critical Discourse 
Analysis (CDA) and Political Discourse Analysis (PDA).

DA is the examination of language and the manner in which it influences and is influenced by society (Taylor, 2013). It is used within disciplines ranging from sociolinguistics to computational linguistics (Jensen et al., 2016). CDA is a form of DA that specifically examines the role of power and dominance within discourse (both spoken and written) occurring within a society. CDA gained popularity in the field of research when Fairclough (1989) introduced the three principal elements of discourse: text, interaction and context. CDA not only studies linguistic forms, but also their communicative purpose (Yule \& Brown, 2003, p.1). Speech analysis requires not merely knowledge of semantics, but also an in-depth knowledge of language in order to understand the practice of successful communication. CDA focuses on inequality, social relationships and power, often within a political context. CDA adopts a multidisciplinary perspective that can be applied to many areas of discourse, and one of the key elements an analyst must be aware of is his/her own position in culture and society (Van Dijk, 2008, p. 85).

Van Dijk (1997, p. 34) notes that: Classical rhetoric, apart from its uses in the courtroom, was primarily developed as an "art" to persuade people in a political assembly. Thus, special arguments, special forms and figures of style were traditionally associated with political text and talk. This applies to political discourse, since politicians use figures of style in order to include a group and exclude another. This research examines Saudi diplomats at the General Assembly of the United Nations for the purpose of creating an inclusive identity for the Kingdom of Saudi Arabia and Arab Gulf States within the international community while excluding Iran.

Political discourse can cover a wide range of discourse including ministerial speeches, press briefings and releases, conferences, parliamentary debates, party manifestos, electoral controversies and arguments, hearings, and propaganda. PDA is a group of analytical 
tools that can be used to uncover themes in the discourse of an individual or an institution, e.g. issues such as racism, chauvinism, etc. Some of the semantic tools used to analyse political discourse include rhetoric, antithesis, contrast, repetition and word count, idiomaticity, euphemism, metaphors, metonymy, analogies and parallelism, stereotypes, symbols and referents, denotations and connotations, explication and implication, stimulus and response, ambiguity, synonym, antonym and hyponym, collocation, clichés and diction. Some syntactic tools include the use of pronouns and demonstratives, modality, mood, transitivity, and negation, to mention but a few.

\section{Research Problem}

Relevant to the role of scientific research in figuring out the political situation and the reasons beyond the political and ideological negative behavior of Iran in the region, the problematic of this research work is to identify the phenomenal elements and the core of this remarkable change in the Saudi political discourse towards Iran.

The problematic area of this research work is to identify the phenomenal elements and the core of this remarkable change in the Saudi political discourse towards Iran, and the reasons beyond the political and ideological negative behavior of Iran in the region.

\section{Research Objective}

This paper is intended to:

1- Identify the characteristics of Saudi political discourse towards Iran and their changes over time

2- Use CDA as a methodological approach.

3- Apply this to a sample of speeches made by Saudi diplomats in reference to Iran at the UN General Assembly sessions.

\section{Literature Review}

Much has been written about the rise of DA, CDA and PDA and the theoretical frameworks underpinning these analytical methods. In this review of the existing literature, special attention is given to 
studies using PDA conducted from 2000 onwards.

Graham et al. (2004) adopted Wodak's discourse-historical approach to examine the significance of George W. Bush's (2001) declaration of a "war on terror". They compared this with three other historically significant "call to arms" speeches by Pope Urban II (1095), Queen Elizabeth I (1588), and Adolf Hitler (1938) in order to identity common features and contrasts in the structure and function of these texts in western societies over the last millennium. The researchers identified four generic features that have endured in such texts throughout this period: (i) an appeal to a legitimate power source that is external to the orator. (ii) an appeal to the historical importance of the culture in which the discourse is situated; (iii) the construction of a thoroughly evil Other or l'autre; and (iv) an appeal for unification behind the legitimating external power source. It is argued further that such texts typically appear in historical contexts characterized by deep crises in political legitimacy.

Using Halliday's systemic-functional framework, Dunmire's study (2005) analysed President Bush's speech on 7 October 2002, in which he presented his rationale for war against Iraq to a lay, public audience. The study shows that the nominalization 'threat' functions in multiple ways to construe a particular vision of future reality. Systematic contrasts in modality serve to privilege this future reality over alternative visions and, simultaneously, to implicate the public in the Administration's vision. Dunmire argues that the President's speech played a significant role in facilitating the conceptual, linguistic, and political change articulated through the preemption policy.

Wang (2010) analyzed the speeches of President Obama at the height of so-called 'Obamamania', concluding that weighty ideas need weighty words to have effective results. Wang concluded that Obama used simple words and short sentences instead of complex vocabulary and sentence structure. Transitivity analysis shows that Obama 
favored the process of doing as reflected in his speeches.

Bird (2011) investigated the rhetorical style in speeches delivered by President Clinton during the critical moments of a domestic tragedy. Bird claims that most rhetoricians have used generic criticism to analyze Clinton's mastery of apology, but have ignored his mastery of rhetoric outside the scandal as a great communicator and user of language.

Amaireh (2013) conducted a rhetorical analysis of the speeches made in English by Queen Rania of Jordan, paying special attention to gender. This study is a contribution to women's studies, in general, and analysis of women's political discourse in particular. Women's speech in the political arena is under-researched, especially the political discourse of Arab and Muslim women in the Middle East. The qualitative and quantitative analysis reveals that women's political discourse has common features such as using personal experience to construct political decisions, being inclusive, believing in achievements, not mere words and promises and prioritising women's issues and supporting their rights in the political arena. It is argued that figures of speech such as metaphor and metonymy are not only used for ornamentation to make the speeches appealing to the audience; they are also used to call the audience to action and convince them to adopt certain ideas.

Salahshoor et al. (2013) analyzed two famous speeches, "The Ballot or the Bullet" by Malcolm X and "I Have a Dream" by Martin Luther King using Bakhtin's concept of Dialogism and the theory of "l'autre" or "the other".

Al-Faki (2014) analyzed the political speeches of some African leaders from a linguistic perspective, concluding that the politicians under study used many rhetorical and metaphorical devices. These devices were highly effective in manipulating the mind of the mob, covering and softening truths and befogging the thoughts. Pronouns and lexical choices are also used by politicians as linguistic tools that 
are used to persuade and manipulate the audience.

Al-Haq et al. (2015) analyzed three important speeches made by King Abdullah II of Jordan using CDA principles. Findings showed that King Abdullah II employs four strategies key to deliver his messages effectively, namely, creativity, reference, circumlocution, and intertextuality. Al-Haq et al. (2015) recommended applying other aspects of strategies of political discourse to King Abdullah's speeches: indirectness, euphemism, disclaimers, etc.

Rabab'ah et al. (2015) applied the concept of hedging to speeches by the same Jordanian monarch. They concluded that the most frequently used hedging device in King Abdullah's speech is modal auxiliaries, more specifically the modal auxiliary "can". Their findings suggest that these hedging devices fulfill several pragmatic functions. Their study also shows that the types of hedging devices and the functions they perform remain constant across English and Arabic (the latter being King Abdullah II's second language). Moreover, unlike scientific discourse, political discourse uses hedging devices to express indirectness, politeness, lack of commitment and probability.

Al Majali (2015) explores the linguistic features of the political speeches made by Arab presidents ousted during the Arab Spring Revolutions. The study focuses on seven speeches delivered by the Tunisian president Zain Al-Abedeen Bin Ali, the Egyptian president Hosni Mubarak and the Libyan leader Muammer Al-Gaddafi during the period from December 2010 to December 2012. Data was analysed using Halliday and Hassan's (1976) framework of cohesion. Results show that the political speeches delivered by these presidents during the Arab Spring Revolution have distinctive lexical features which differ from their previous speeches. Repetition, synonymy and hyponymy are widely used in these speeches to represent different political ideologies and strategies.

Hussein (2016) analyzed the speech made by Egyptian President Sisi at the opening of the new Suez Canal. She concluded that he 
made extensive use of intertextuality, combined with figures of speech, repetition, synonymy and collocation not only to elevate the linguistic style, but also to serve various ideological purposes. These included influencing and persuading his audience. The use of different discourse registers in Sisi's speech, combined with extensive use of repetition, served not only to demonstrate his stylistic command, but also to convey his views, manifested in his attempt to create a lasting impact on the audience for his speech.

Within this context of the prior research work the main objective of this study is to trace the shifts in Saudi political discourse towards Iran during the period from 1947-2018 examining the extent to which these correspond with escalations in tension between Saudi Arabia and Iran.

\section{Methodology}

This study focuses on a corpus consisting of speeches made by Saudi diplomats at the General Assembly of the UN from 1947 to 2018. The corpus consists of 22 speeches delivered by Saudi diplomats and representatives at the UN General Assembly during the period from December 1947 to December 2018. These speeches were downloaded from the UN website (see Appendix for internet links). Analysis of this material provides insights into shifts in Saudi Arabia's political discourse from the establishment of the UN in 1947 to the ongoing crisis in Yemen.

Using framing and rhetorical tools of persuasion together with an adapted version of Fairclough's (1992) CDA as an approach, this paper analyses a sample of speeches made by Saudi diplomats in reference to Iran at the UN General Assembly sessions with the purpose of identifying the characteristics of Saudi political discourse towards its allies on the one hand and Iran on the other and their changes over time. This interdisciplinary methodological approach includes contextualizing of the discourse under study within a sociopolitical, historical, ideological and linguistic framework. The tools 
employed from the approaches outlined by Fairclough' s framework (1992: 75) include vocabulary (diction, metaphors), grammar (modality, transitivity), cohesion, coherence and intertextuality.

\section{Framing}

In discourse, frameworks are the ways in which we mentally compose background knowledge to understand a delivered speech or a written text, and also to produce a discourse. They can also be described as systems and structures representing stereotypical attitudes. When we face a situation we mentally choose a framework that helps us to understand the situation and interact with it. Thus, frames form part of our memory and help us understand the world around us.

Framing is a way of shaping the world as well as seeing it, and is a powerful political tool. In political discourse, language is always arranged to evoke certain frames, which reflect a particular ideology (Lakoff, 2004, p. 3). Policy framing can also be used in framing foreign policy and institutions that implement these policies, affecting how one nation perceives another as allies or enemies.

Lakoff (2004, p. xv) explains that rephrasing or reframing changes the way the public perceives the world. It changes what is considered common sense. Because language activates frames, new language is required for new frames. Thinking differently means talking differently. Thus, framing and restructuring are tools that we must understand and consider when looking at political discourse. This paper examines the frames used by Saudi speakers at the General Assembly of the UN to convey their country's political position in relation to those it wishes to consider as allies (the Gulf States) and enemies (Iran).

\section{Rhetorical Tools of Persuasion}

As this paper principally focuses on the speeches delivered by Saudi officials at the UN General Assembly, it is interesting to 
consider the role of persuasion in this discourse, as persuasive language targets the emotions and expectations of the listeners rather than their rational mind. It focuses on convincing the audience and projecting trustworthiness rather than being informative (Sornig, 1989 , p. 109). One of the main features of persuasive discourse is to seem plausible and to make use of pathos and ethos (to use Aristotle's terminology) when communicating one's message. Identification of the persuasive techniques used by Saudi diplomats in their speeches also forms part of this analysis.

\section{Pronouns and deixis}

CDA also pays close attention to how grammar is used in sentence construction and discourse syntax. Deictic elements are parts of speech that refer to person, time or place in a written or spoken piece of discourse and which cannot fully be understood without additional contextual information. According to Levinson (2012, p. 54) "Deixis is the most obvious way in which the relationship between language and context is reflected in the structures of language themselves." There is a strong link between person deixis and personal pronouns.

\section{Primary Analysis}

\section{Framing:}

Framing in Saudi diplomats' discourse plays a major role in their communication of the Kingdom's values. As previously noted, frames are mental structures which we use to categorize and thus comprehend the world around us. Frames help people make sense of situations and once a frame is created, it can be very difficult to alter.

\section{Battle Frame}

Prince Saud Al-Faisal's discourse relies very heavily on the battle frame. This frame is triggered by lexical items such as 'wars', 'armed conflicts' and 'weapons of mass destruction'. However, in this context Prince Saud and the Arab members of the UN are fighting for a 
nuclear-free zone against Iran and Israel. By using this frame, Saudi Arabia's chief diplomat creates a particular feeling amongst General Assembly members - a feeling of a peace-loving nation, so this frame is deeply linked with the patriotic frame, as it has some of the same elements.

Prince Saud frames the Iranians and Israelis as bad people who do not want the best for the region. He makes this crystal clear when he says "the Middle East region - which has suffered a number of wars and armed conflicts and become a stockpiling and production area for a variety of weapons of mass destruction". Nizar Obaid Madani also reiterates that "The Government of the Custodian of the Two Holy Mosques is keenly interested in the ongoing efforts to eliminate weapons of mass destruction in the Middle East, including the Arabian Gulf region", which emphasizes the battle frame. Fawzi Shobokshi also refers to the "unresolved issue of Iran's nuclear program" in his address to the UN General Assembly. The battle frame is also used by Saudi Foreign Minister Al-Jubier during his speech on 1 October 2015 before the UN General Assembly. In his speech he explicitly accuses Iran of "exacerbating" and "escalating" the crisis in Yemen through "incitement" and "arms' smuggling". $\mathrm{He}$ gives an example of an Iranian ship "laden with arms" for the rebels in Yemen that had been "intercepted

\section{Family Frame}

The family frame is one of the frames Saudi diplomats use in their speeches. Al-Jubier used it in his 1 May 2015 speech when he referred to the 'brotherly people of Yemen', and the 'sisterly United Arab Emirates'. The whole Gulf region is treated by him as one big family. By evoking the family frame, he becomes closer to his audience, as he is implicitly saying 'I am one of you. You are my family', but he is also making sure that when he talks about family, everyone knows exactly what kind of values he is referring to. In his 1963 speech to the General Assembly, Rashad Pharaon used the word 'brothers' twice 
in reference to the Yemeni people. It is worth noting that the Egyptian Army entered Yemen in 1962. Prince Abdulaziz, in his 1963 speech before the General Assembly used the word 'brothers' in reference to the Yemenis. In his 1985 speech to the General Assembly, Prince AlSaud referred to both Iraq and Iran as 'two brotherly nations'.

\section{Prosperity Frame}

The prosperity frame is concerned with the development of the Middle East region. This frame is evoked by Prince Saud Al-Faisal's lexical items such as 'development assistance' and 'more available resources'. These are possibly the words that the Saudi chief diplomat would like the General Assembly to think about, when the Iran-Iraq war comes to their minds. Most of his speech is about development, as that is the most important thing if the Middle East and the Gulf region are to prosper. Therefore, he has to have a very strong development plan, if this conflict ends. He also has to make sure that his development plan is framed in the right way, so that the regional powers know exactly what to expect from the Government of Saudi Arabia, and that may explain why he spends so much time on this in his General Assembly speech. In his speech to the General Assembly on May 1, 2015, Saudi Foreign Minister Al-Jubier used the lexical items 'international humanitarian assistance', 'education', 'health care' in his reference to the aid extended by the Saudi Government to the Yemenis living illegally in the Kingdom.

\section{Persuasive Techniques}

The analysis now turns its focus to persuasive techniques in Saudi diplomats' General Assembly speeches on Iran. First, Saudi diplomats stressed that financial resources were assigned to development in the region before the outbreak of the Iraqi - Iranian war. Saudi Foreign Minister Saud Al-Faisal said in 1980"Before the outbreak of the IraqiIran war we had more available resources that would have enabled us to offer a larger volume of development assistance. However, that long war consumed them." He does not consider these two sentences 
enough to convince the General Assembly; he gives Arab citizens the right to wonder why development efforts in the region diminished. $\mathrm{He}$ added "it is the right of the Arab citizen to wonder today over the causes of the diminished Arab development efforts in realizing his aspirations and ambitions."

In another spot he demanded "We call on Iran to renounce its meddling in Arab affairs, which we will firmly resist in our desire to build good-neighborly relations with Iran, based on mutual respect, good neighborliness and non-interference in the affairs of other countries." (2015 speech). In the (2016 speech) he resumed "We seek good relations with Iran based on the principles of goodneighborliness and non-interference in other countries' internal affairs. On the contrary, the 2017 and 2018 Saudi speeches were void of any traces of flattery.

In the year 2018, due to the radical negative transformation in the Saudi - Iranian relationship, the Saudi discourse is holistically directed to the UN with the aim of pinpointing the political misbehavior of Iran. Therefore Saudi Arabia believes: "that the achievement of peace and settlement in the Middle East necessitates an action against Iran's policy of expansion and destruction in the region."

\section{Vocabulary:}

\section{Diction:}

There are remarkable changes in the process of the political discourse of Saudi Arabia towards Iran during the years 2015, 2016, 2017 and 2018 in regard to the nuclear programme for free zone that is why there has been a mutual understanding between Saudi Arabia and the countries $\mathrm{p} 5+1$ in resisting Iran's strategic plan of expansion in the area. That was apparent in the year 2015 speech delivered by Mr. Al-Jubeir who called "for a zone free of nuclear and other weapons of mass destruction in the Middle East". 
During the year 2016 there has been an assertion of all nuclear and weapons of mass destruction elimination from the Middle East in general and gulf area in particular. That has been indicated in the political speeches of that year.

There has been a lowering tone of consideration of this issue viable in the 2017 discourse as the Minister of Foreign Affairs indicated: "My country was one of the first to call for establishing a zone free of nuclear weapons and other weapons of mass destruction in the Middle East."

During the 2018 it has come to rise deeply again in reference to the Saudi Arabia emphasis on the agreement of the nuclear weapons issue along with the USA strategy in an attempt to strongly stop Iranian expansion in the area.

\section{Metaphors:}

Due to the straightforwardness of Saudi Political Discourse towards Iran, there has been no room for the implication of the metaphorical language. That is to say Saudi discourse relied on explicit denotation rather than implicit connotation.

\section{Grammar:}

\section{Modality}

For Martins and David (2003), modality is a way of introducing attitudinal voice to discourse. In a corpus of 2490 words, modals occurred only 11 times. "Cannot" occurred twice, "will" three times, "need" three times and "would" in a modal perfect phrase once. It is significant that "must" did not occur at all, a matter which indicates the polite and diplomatic nature of the Saudi discourse. "Must" indicates strong obligation and is a tough defective verb that - once uttered - creates an atmosphere of tension. "Must" was replaced by "should" which recurred three times to show slight obligation. "Should", however breaks the norms of diplomacy when it is employed in certain structures to mean "must" as in "Iran should be 
held accountable in the international legal system."

\section{Transitivity}

According to Burton (1982: 200), transitivity is used: "to describe the scenario of "who does what to whom"'. Usually an intransitive verb initiates an action that rebounds on the subject or the doer. By contrast, a transitive verb leaps forward on the recipient of the action. Transitive verbs break down into mono-transitive and di-transitive.

Apart from linking verbs, causative verbs, auxiliaries and helping verbs, some 89 dynamic verbs are used in the corpus, five of which are in the passive mode, a matter which signifies frankness and straightforwardness in the Saudi discourse. Thirteen verbs are intransitive and the rest are transitive. This shows that the Saudi discourse is daring. It shows also that it triggers off events and demands action. It has been noted that about two-thirds of the 76 transitive verbs reveal positivity, most particularly in the case of Saudi Arabia. Here are some examples:

- $\quad$ achieve security and stability

- $\quad$ find a political solution

- $\quad$ settle the dispute

- $\quad$ expressed its support

- limit the proliferation of weapons

- eliminate weapons of mass destruction

- $\quad$ improve the climate

- $\quad$ realize the aspirations)

- $\quad$ intensify efforts

- mobilize international humanitarian assistance

- $\quad$ improve the conditions

- $\quad$ provide employment, education and health care

- $\quad$ build good-neighborly relations

- $\quad$ seek good relations

But when Iran is in question, shadows of negativity broods 
over the speech as in the following examples that represent the remaining one-third:

- initiate a military intervention

- $\quad$ suffer a number of wars

- $\quad$ attack ships

- destroy hopes

- $\quad$ spread disruption

- demonstrate hostility

- $\quad$ placed mines

- $\quad$ push the region into a storm

- $\quad$ threaten the security and stability

- $\quad$ violate laws

- $\quad$ Reject international conventions

- $\quad$ made allegations

\section{Cohesion:}

\section{The Use of Conjunctions}

Prince Saud used the conjunction 'however' to emphasize the changes that took place after the outbreak of the Gulf War to the audience. He extends his persuasive technique to include Arab citizens who must have been following his speech. In the UN, officials represent their citizens. So it acts as a useful persuasive technique by the Royal Prince in his 1 May, 2015 speech.

\section{Cause and Effect:}

Cause and effect is also an effective persuasive technique. It was used by Omar Sakkaf in his 1964-5 speeches to the General Assembly. He persuaded the GA to take "positive decisions" relating to "disarmament and the spread of nuclear weapons" so that "fear may be dispelled and tension lessened amongst peoples and nations everywhere". On 28 September 2012, the Saudi envoy to the UN, 
Prince Abdulaziz used the same persuasive technique when he called upon the Yemenis to "stand against foreign interference". He meant of course Iran. He pointed out that the effect would be "security and stability."

During the 2018 Saudi's speech in the UN assembly the Iranian expansive attempts, destructive methods and its plans for intervention in the political affairs of its neighbors resulted in making Iran subject to international punishments.

In conclusion, through persuasive techniques, Saudi diplomats create an international in-group relation among all General Assembly members asking them to be aware of the issues in the Middle East and the Arabian Gulf area and urging them to take action when it comes to threatening peace and security.

\section{Use of Pronouns:}

\section{The pronouns 'me', 'my' and 'I'}

'Me', 'my' and 'I' are all pronouns which refer to the speaker only. The interesting thing about investigating Saudi speakers' use of the personal pronouns is to see how they are framing themselves in the discourse as shown by the following examples:

I may cite such issues as disarmament, the limitation of nuclear weapons and their spread among more nations, and, nonetheless, the urgent need for States to settle their disputes by peaceful means. I do trust that the General Assembly will, during this session, take positive decisions for the solution of these problems, especially these relating to disarmament and the spread of nuclear weapons, so that fear may be dispelled and tension lessened amongst peoples and nations everywhere. (Sakkaf, 1964-1965)

My country has opened its doors to hundreds of thousands of Syrians. My Government, which has sincerely collaborated with the United Nations, is prepared to give its honest and loyal support to any effort designed to produce a peaceful, just and equitable solution to 
this problem (Pharaon, 1963)

In the examples above, the communicative function of the person deixis is to draw the audience's attention to the speaker. Both speakers communicate a statement concerning KSA's position regarding the crisis in Syria, in which Iran interferes. They used the pronouns ' $I$ ' and 'my' that both create a personal reference. In these instances, the two Saudi diplomats are fully responsible for what is being said; thereby, the statement can have consequences only for their country.

\section{The pronouns 'we' 'us' and 'our'}

Before the outbreak of the Iraqi-Iran war we had more available resources that would have enabled us to offer a larger volume of development assistance. (Prince Al Faisal, 1990)

'We' involves the speaker and the Saudi people. Prince Al-Faisal informs his audience that the Kingdom of Saudi Arabia can have an influence on the future economy of the region if Iran stops its interference.

The same token applies to the statement of Al-Jubier (2005) who said

Our aim is to find a political solution based on the Gulf Cooperation Council initiative, the conclusions of the national dialogue, and Security Council Resolution 2216 (2015).

In the same address, Al-Jubier goes on using the pronouns 'we' and 'our' to have the same effect:

Our Kingdom and our partners are intensifying efforts in order to mobilize international humanitarian assistance to Yemen

The phrase 'our Kingdom and our partners' gives a sense of inclusiveness showing identification with the people included in the communicative situation, namely the coalition:

We welcomed the recent agreement between the P5+1 and the Islamic Republic of Iran,

We call on Iran to renounce its meddling in Arab affairs, 
We also call on Iran to end its occupation of the three islands in the Arabian Gulf belonging to the sisterly United Arab Emirates.

(Al-Jubeir, 2015)

Additionally, as mentioned in the theoretical framework, even though Al-Jubier is the spokesman and has the authority in the communicative situation, he still maintains equality between himself and the General Assembly members because they are 'on the same side' (Fairclough, 2001, p. 106).

\section{The pronouns 'they' 'them' and 'their'}

In reference to the Yemeni people, the Saudi diplomat used the pronoun 'they' in the phrase "they who will decide their own future" (Pharaon, 1963) as did Al-Jubier in his 2015 speech when he said:

Although we recognize that the Houthis are part and parcel of the social fabric in Yemen, that does not give them the prerogative to own militias outside the framework of the State of Yemen or at the expense of the rest of the Yemeni people. (Al-Jubeir, 2015)

'They' and 'them' are pronouns which refer to someone or something in the out-group. The Saudi speakers used these pronouns to create division among two groups of people: the Yemeni people versus the foreign military intervention in the first example and the Yemeni people in general versus the Houthis in particular. They are used as a political tool in order to create solidarity within one group and exclude others from the context.

The very many different numbers of the use of such pronouns as "our, we, us and they" shown in the last four Saudi speeches emphasize the centralization and globalization of the power of the Saudi discourse. The connotation of using pronouns "we, our and us" in regard to the Saudi - Iranian relations indicates the power of the Saudi political discourse in that at one level of understanding, the three afore - mentioned pronouns show the nationalistic attitude as well as the internationalistic and globalisic attitude towards Iran. The 
Saudi discourse has been successful in employing the pronoun "we" on three different levels: the Saudis among themselves, Saudis with the neighboring countries and the Saudis within the context of the international scene.

\section{Coherence:}

There are two levels of coherence in the Saudi political course. The one is semantic in that though Iran continues to politically misbehave in the region, the Saudi discourse remains consistent seeking good relations with Iran. The other technically connects with the use of such tools as 'meanwhile' and 'turns to' to comparatively contrast and signal the vacillation the two opposites natures of the relationship.

Thus the two levels of coherence manifest the Saudi sense of an uneasiness signaled in Iran's constant search for socio-cultural, ideological and political domination of the region.

\section{Intertextuality:}

There is a kind of intertextuality in the Saudi political discourse in regard to the 2015 and 2018 speeches towards the nuclear agreement concluded with Iran. In 2015, the Saudis welcomed the agreement of P5 +1 . There has been an assertive Saudi political discourse that shows a real sense of welcoming an agreement. Meanwhile, the 2018 speech shows remarkable rising up of the Saudi political discourse that shows clear sense of support to American strategy of withdrawing from the World Nuclear Agreement with Iran.

\section{Secondary level of Analysis}

Relevant to the secondary level of analysis, it is concluded that the constant tension between Saudi Arabia and Iran has been subject to to escalation and de-escalation due to the changing political circumstances between the two countries on the one hand and the neighboring countries on the other.

During the period 1947-1957 there was no mention of any Iran- 
related terms by Saudi permanent representatives or visitors at the UN General Assembly. The first allusion to any Iranian-related discourse came from Mr. Shukairy in October 1957 who referred to the rise of Arab Nationalism, probably inspired by President Nasser of Egypt. The Islamic Revolution in Iran began in January 1978 and lasted until February 1979, but no mention was made of this by Saudi representatives during UN sessions. In fact, Iran was mentioned for the first time in October 1980 by Prince Saud Al-Faisal in the context of the First Gulf War.

The first escalation of Saudi-Iranian tensions was recorded in September 1987 in connection with the riots by Iranians during the pilgrimage to Mecca. On 30 September 1991, Prince Al-Faisal called for a nuclear-free Middle East. Reading between the lines, he was alluding to the Iranian program. However, Israel's nuclear program became functional in 1964, and its air force bombed the Iraqi reactor in 1981. Saudi Arabia has also supported the Pakistani program as a means of keeping both India and Israel in check.

On 29 September 1992 Saudi Arabia alluded, for the first time, to Iran's occupation of three Emirati islands (Abu Musa and the Greater and Lesser Tunbs) on 30 November 1971. On 30 September 1999, the first hint about clearing the Gulf area and the Middle East from nuclear power was made. On 28 September 2012, the Saudi envoy to the UN called for Yemenis to stand up against foreign interference, clearly a reference to Iran. During the UN session held on 1 October 2015, references to Iran became explicit rather than implicit. Finally, on 23 September 2017, the Saudi spokesman bluntly denounced Iran's role in Syria. Recently in September 2018, the Saudi discourse towards Iran was outspoken as it directly accused Iran of intervening and destabilizing the region. It also called on the international community to deter Iran and curb its expanding and destructive strategy in the region.

The following analysis represents in graphical and tabular 
presentations the speeches of Saudi officials at the UN after putting them into a corpus form. The following graph (Figure 1) shows the cornerstone years in the escalation in Saudi-Iranian political tensions:

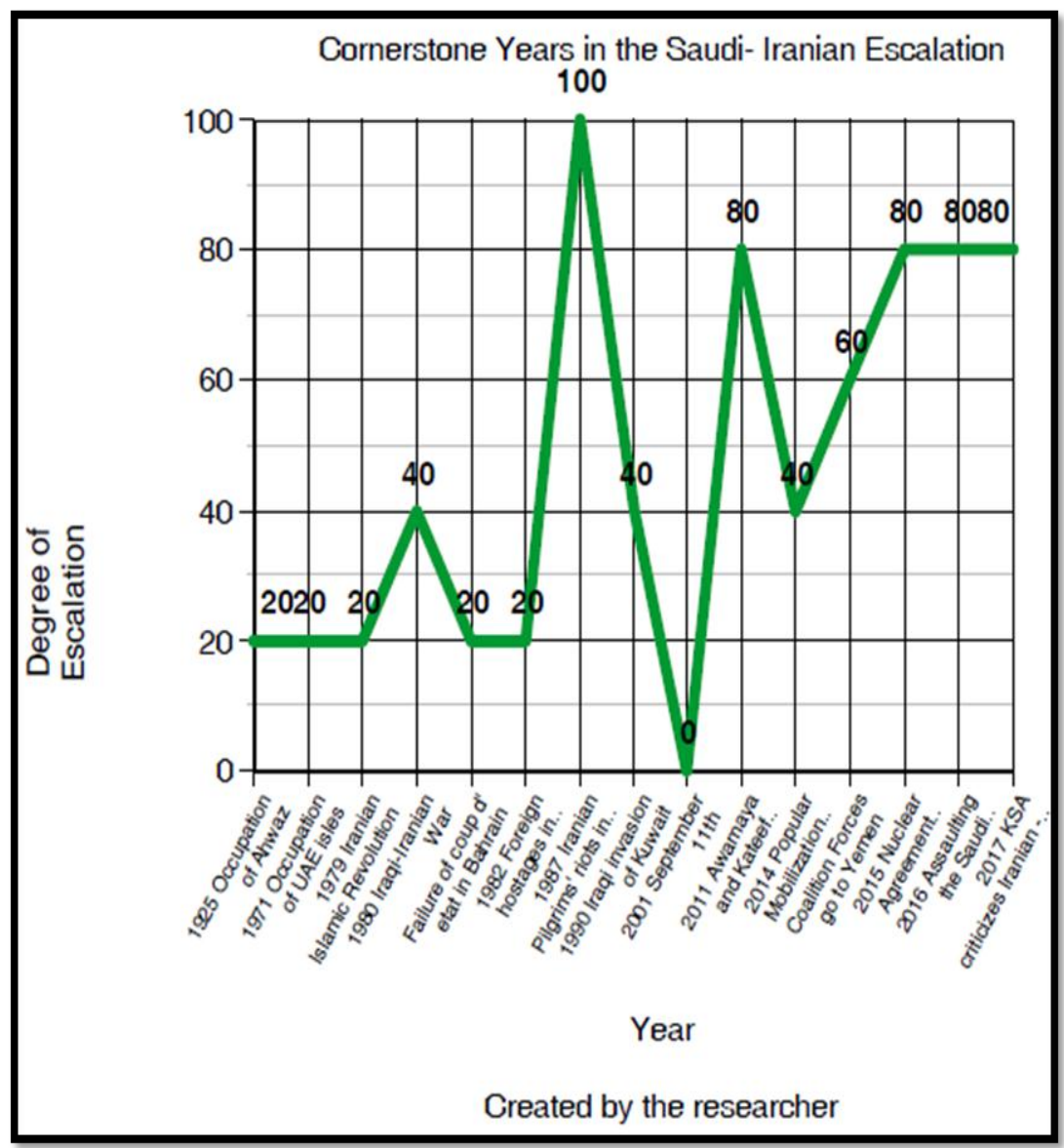

Figure 1: A diagram showing the cornerstone years in the SaudiIranian escalation

As shown in Figure 1, the highest level of escalation of tensions in Saudi-Iranian relations occurred in 1987 when Iranian pilgrims disturbed the peace of pilgrims performing Haj at Mecca, at the holiest shrine for Muslims. From 2014 onwards, the escalation did not come to a halt. 


\section{Word Count and Collocations}

In all the speeches given by Saudi representatives and diplomats at the UN General Assembly sessions over the period 1947-2018 the following words recurred:

Table 1: Frequency count of the word Iran in Saudi speakers' speeches

\begin{tabular}{|l|l|}
\hline Word & Number of Times \\
\hline Iran & 37 \\
\hline Iranian & 10 \\
\hline Nuclear & 10 \\
\hline Shia & 0 \\
\hline
\end{tabular}

It is clear from the word count that "Iran" and "Iranian" were mentioned 43 times, showing that they represent an essential factor in Saudi Foreign policy. However, the word "Shia" recorded a zero occurrence in Saudi discourse, indicating that the Saudis have no ideological issues with Iran. KSA is reported to have $15 \%$ of Shia population living in welfare and prosperity among their Sunni compatriots. Iran has been saving no effort to provoke Saudi Shiites.

The collocations for the word "Iranian" were as follows:

Table 2: Collocation of the word Iran in Saudi speakers' speeches

\begin{tabular}{|l|l|}
\hline Word & Number of Times \\
\hline Iranian authorities & 4 \\
\hline Iranian occupation & 1 \\
\hline Iranian response & 1 \\
\hline Iranian regime & 1 \\
\hline Iranian people & 1 \\
\hline Iranian leaders & 1 \\
\hline Iranian ship & 1 \\
\hline
\end{tabular}

The previous collocation table shows that the Saudis do not have a problem with the people of Iran, but rather with those who govern 
Iran represented by "authorities", "regime" and "leaders". Notice that the first two words are often used by Arabs to refer to the Israelis.

Saudi speakers have only criticized unlawful acts by the Iranian authorities since the outbreak of the First Gulf War. Saudi condemnation of Iranian intervention in the Arab region in general and the Gulf region in particular was relatively muted until 2014 when Iran flagrantly interfered in Yemen and threatened safe navigation through international maritime routes. The young leadership of Saudi Arabia, represented by Saudi Crown Prince Mohamed bin Salman, and the new young Saudi Foreign Minister Adel Al-Jubier used tougher language in a way that matched the escalation in SaudiIranian tension. Although Iran occupied the UAE's islands in November 1971, this issue was only mentioned in Saudi speakers' speeches in 1992.

\section{Conclusion}

This paper set out to uncover underlying discursive structures in Saudi diplomats' discourse with a specific focus on persuasive techniques and aspects of inclusion and exclusion by means of the methodologies of CDA. The analysis focused on a corpus of Saudi speakers' speeches at the UN General Assembly from 1947 to 2018. The analysis revealed a high representation of person deixis pronouns and all with the function of either inclusion or exclusion of countries within the communicative context, namely, the UN General Assembly. To a great extent, Saudi discourse relies on carefully designed frames which are all heavily intertwined. The most dominant frames revealed by the analysis were: family, battle, and prosperity frames. All of the above findings point to how highly constructed Saudi diplomats' discourses actually are, and one might argue that all of the above factors are key players in Saudi narrative about Iran as suitable for the General Assembly.

Some of the speeches analyzed here were made at times of increased political tensions within Saudi-Iranian relations. The highest 
level of escalation came in 1987 during Iranian pilgrims' riots in Mecca. The escalation reached another peak in 2014 onward since Iran intensified its intervention in the Yemeni and Syrian conflicts.

Applying the tools of discourse analysis proved the validity of the research hypothesis. The main purpose of Saudi diplomats' discourse is to construct a narrative which sets Saudi Arabia and its sister Gulf States in opposition to Iran.

In spite of the escalation in tensions, the Saudi speakers at the UN General Assembly observed diplomatic norms in their discourse. The language used went up and down in accordance with the actions on the ground. There has been no attack on the Iranian people

Saudi discourse has been balanced and diplomatic. It is a discourse that prefers mitigation to a limit. Due to the straightforwardness of Saudi Political Discourse towards Iran, there has been no room for the implication of the metaphorical language. That is to say Saudi discourse relied on explicit denotation rather than implicit connotation.

The research paper concludes as well that the changing discourse of Saudi diplomacy towards Iran is due to the changing political behavior of Iran in the Gulf area. 


\section{References:}

Amaireh, H. A. (2013). A rhetorical analysis of the English speeches of Queen Rania of Jordan, PhD thesis, University of Aberdeen.

Al-Faki, I. M. (2014). Political speeches of some African leaders from linguistic perspective (1981-2013). International Journal of Humanities and Social Science, 4(3), 180-198.

Al Haq, F. Al-Abed and Al-Sleibi, N. M. (2015). A critical discourse analysis of three speeches of King Abdullah II, US-China Foreign Language, 13(5), 317-332, doi:10.17265/1539-8080/2015.05.001.

Al Majali, W. (2015). Discourse analysis of the political speeches of the ousted Arab Presidents during the Arab Spring Revolutions using Halliday and Hasan's Framework of Cohesion. Journal of Literature, Languages and Linguistics, 10, 35-48.

Bird, C. (2011). The Discourse of American Tragedy: An Analysis of President Clinton's Rhetoric as it Functions to Construct Reality, Shape Community, and Display Presidential Eloquence. MA thesis, Central Michigan University.

Burton, D. (1982). Through glass darkly: Through dark glasses. In Carter. R (ed). (1982) Language and Literature: An Introductory Reader in Stylistics. London: Allen and Unwin.

Dunmire, P.L. (2005). Preempting the future: Rhetoric and ideology of the future in political discourse. Discourse and Society, 16(4), 481-513.

Fairclough, N. (1989). Language and Power. Harlow; New York: Longman.

Fairclough. N. (1992). Language and power, 2nd edition. London: Longman Press.

Fairclough, N. (ed.) (1992) Critical Language Awareness. London: Longman.

Graham, P., Keenan, T. and Dowd, A. (2004). A call to arms at the end of history: A discourse-historical analysis of George W. Bush's declaration of war on terror. Discourse and Society, 15(2-3): 199-221.

Hussein, I. (2016). Critical discourse analysis of the political speech of the Egyptian President, Abdel Fattah El-Sisi, at the New Suez Canal inauguration ceremony. International Journal of Language and Literature, 4(1), 85-106.

Jensen, I., Koch Jakobsen, I. And Pichler, L.H. (2016). A Critical Discourse Study of Hillary Clinton s 2015/2016 Presidential Campaign 
Discourses, MA thesis, Aalborg University, http://projekter.aau.dk/projekter/files/239472135/Master_s_Thesis.pdf

Lakoff, G. (2004). Don't Think of an Elephant. Know Your Values and Frame Your Debate. Vermont: Chelsea Green.

Levinson, S. C. (2012). Pragmatics. Cambridge, MA: Cambridge University Press.

Martins, J. R. and David, R. (2003). Working with Discourse: Meaning beyond the Clause London: Continuum.

Salahshoor, F., Baggali, H and Behin, B. (2013). Critical discourse analysis of two political speeches in light of Bakhtin's dialogism. Biannual Journal of Applied Linguistics and Discourse Analysis, 1(2), 87-107

Rabab'ah, G and Abu Rumman, $\underline{\text { R. (2015). Hedging in political discourse: }}$ Evidence from the speeches of King Abdullah II of Jordan. Prague Journal of English Studies, 4(1), 157-185.

Sornig, K. (1989). Some remarks on linguistic strategies of persuasion. In Wodak, R. (ed.) Language, Power and Ideology: Studies in Political Discourse. (pp. 95-113) Philadelphia: John Benjamins.

Taylor, S. (2013). What is Discourse Analysis? London: Bloomsbury.Van Dijk, T. (1997). What is Political Discourse Analysis? In J. Blommaert and C. Bulcaen (Eds.), Political Linguistics (pp. 11-52). Amsterdam: Benjamins.

Van Dijk, A.T. (1997). Discourse as structure and process of discourse studies: A multidisciplinary introduction. Volume I. London:SAGE.

Van Dijk, T. (2008). Society and Discourse. Cambridge: Cambridge University Press.

Wang, J. (2010). A critical discourse analysis of Barack Obama's speeches. Journal of Language Teaching and Research, 1(3), 254-261.

Yule, G. and Brown. G. (2003). Discourse Analysis. Cambridge: Cambridge University Press. 


\section{Appendix}

https://gadebate.un.org/en/73/saudi-arabia (2018)

72nd session [2017, 23 September]: A/72/PV.20: Adel Ahmed AlJubeir

71st session [2016, 21 September]: A/71/PV.11*: Crown Prince Mohammed bin Naif bin Abdulaziz Al-Saud [2016, 19 September]: A/71/PV.4 A*: Crown Prince Mohammed bin Naif bin Abdulaziz Al-Saud (High-level Plenary Meeting on Addressing Refugees and Migrants)

70th session [2015, 1 October]: A/70/PV.24: Adel Ahmed Al-Jubeir 67th session [2012]: A/67/PV.16: Prince Abdulaziz 2010, 20 Sept.: A/65/PV.3 : Khalid Abdalrazaq Al-Nafisee (Highlevel Plenary Meeting on the Millennium Development Goals) 61st session [2006]: A/61/PV.17: Fawzi Shobokshi 2005, 15 September: A/60/PV.6*: Prince Sultan Bin Abdulaziz AlSaud

59th session [2004]: A/59/PV.11: Nizar Obaid Madani 58th session [2003]: A/58/PV.15: Saud Al-Faisal 57th session [2002]: A/57/PV.17: Fawzi Shobokshi 55th session [2000]: A/55/PV.15: Nizar Obaid Madani 2000, 6 September: A/55/PV.3*: Crown Prince Abdullah Bin Abdul Aziz Al-Saud (UN Millennium Summit)

54th session [1999]: A/54/PV.19: Nizar Obaid Madani 53rd session [1998]: A/53/PV.20: Nizar Obaid Madani 1998, 10 June: A/S-20/PV.7: Saleh Al-Shaikh 51st session [1996]: A/51/PV.17: Abdul Rahman Mansouri 49th session [1994]: A/49/PV.17: Prince Saud al-Faisal 48th session [1993]: A/48/PV.28: Gaafar Allagany 47th session [1992]: A/47/PV.17: Prince Saud al-Faisal A/47/PV.17: Gaafar Allagany 46th session [1991]: A/46/PV.15: Prince Saud al-Faisal 45th session [1990]: A/45/PV.16: Prince Saud al-Faisal (A/45/PV.23: Samir Shihabi) 1990, 27 April: A/S-18/PV.7: Samir Shihabi 1990, 22 February: A/S-17/PV.5: Samir Shihabi 
44th session [1989]: A/44/PV.28: Samir Shihabi 43rd session [1988]: A/43/PV.13: Prince Saud al-Faisal 42nd session [1987]: A/42/PV.15: Prince Saud al-Faisal 41st session [1986]: A/41/PV.13: Prince Saud al-Faisal 40th session [1985]: A/40/PV.16: Prince Al-Saud 39th session [1984]: A/39/PV.13: Saud al-Faisal 38th session [1983]: A/38/PV.16: Prince Saud al-Faisal 37th session [1982]: A/37/PV.16: Faisal Alhegelan 36th session [1981]: A/36/PV.25: Saud al-Faisal 35th session [1980]: A/35/PV.23: Saud al-Faisal 34th session [1979]: A/34/PV.21: Saud al-Faisal A/34/PV.32: Samir Shihabi

32nd session [1978]: A/32/PV.21: Saud al-Faisal A/32/PV.27: Jamil Baroody

31st session [1976]: A/31/PV.12: Saud al-Faisal A/31/PV.23): Jamil Baroody

30th session [1975]: A/PV.2365: Saud al-Faisal A/PV.2368: Jamil Baroody 29th session [1974]: A/PV.2253: Omar Sakkaf 28th session [1973]: A/PV.2133: Omar Sakkaf A/PV.2139: Jamil Baroody 27th session [1972]: A/PV.2057: Omar Sakkaf A/PV.2045: Jamil Baroody 26th session [1971]: A/PV.1961: Omar Sakkaf 25th session [1970]: A/PV.1851: Jamil Baroody 24th session [1969]: A/PV.1778: Omar Sakkaf 23rd session [1968]: A/PV.1704: Jamil Baroody 22nd session [1967]: A/PV.1589: Mr Al-Sowayel 21st session [1966]: A/PV.1443: Omar Sakkaf 1966, 24 June: King Faisal Ibn Abdul Aziz Al Saud [visit only] 20th session [1965]: A/PV.1363: Omar Sakkaf 19th session [1964-1965]: A/PV.1306: Omar Sakkaf 18th session [1963]: A/PV.1235: Rashad Pharaon 17th session [1962]: A/PV.1150: Prince Saud al-Faisal A/PV.1148: Ahmad Shuqayri 
16th session [1961]: A/PV.1022: Ahmad Shuqayri A/PV.1038: Ahmad Shuqayri

15th session [1960]: A/PV.879: Ahmad Shuqayri A/PV.899: Ahmad Shuqayri

14th session [1959]: A/PV.808: Ahmad Shuqayri A/PV.823: Ahmad Shuqayri

13th session [1958]: A/PV.766: Ahmad Shuqayri 12th session [1957]: A/PV.697: Ahmad Shuqayri

1957, 29 January: A/PV.647*: King Saud Ibn Abdul Aziz Al Saud 2nd session [1947]: A/PV.89: Prince Fahd 1947, 21 January: Crown Prince Faisal Al Saud [visit only] 1st session [1946]: A/PV.40: Prince Fahd 